AKRUAL 1 (1) (2009): 45-62 $e$-ISSN: 2502-6380

AKRUAL

Jurnal Akuntansi

http://fe.unesa.ac.id/ojs/index.php/akrl

\title{
KAJIAN MEKANISME PERDAGANGAN HAK EMISI KARBON DAN KONTROVERSI PERLAKUAN AKUNTANSI ATAS HAK EMISI KARBON
}

\author{
Rikasari \\ Universitas Negeri Surabaya \\ Email: rikasari2002@yahoo.com \\ Hariyati \\ Universitas Negeri Surabaya \\ Email: aaan_har@yahoo.com \\ Artikel diterima: 6 Agustus 2010 \\ Revisi terakhir: 22 September 2010
}

\begin{abstract}
This article discusses the characteristics of carbon emissions as the negative externalities that previously could not be included in the financial statements. Further explains the history and development of carbon emission rights trading that allows negative externality can be recorded in financial accounting. Various methods are offered based on various accounting standards in order to record transactions of carbon emission rights trading compared and discussed. The complexity of the standard interpretation that is used to record a new problem in an effort to incorporate the negative externalities in the financial statements. At the end of this article, several recommendations for recording transactions of carbon emissions trading has to offer.
\end{abstract}

Keywords: carbon emission rights/carbon emission permits/emission allowance, negative externality, emissions Trading, International Financial Reporting Interpretations Committee (IFRIC) 3.

\section{PENDAHULUAN}

Akuntansi keuangan berhubungan dengan penyediaan informasi yang menyangkut posisi keuangan, kinerja, serta perubahan posisi keuangan suatu perusahaan yang bermanfaat bagi sejumlah besar pengguna dalam pengambilan keputusan ekonomi (Kerangka Dasar Penyusunan dan Penyajian Laporan Keuangan, SAK 2009). Oleh karena itu akuntansi keuangan dikembangkan berdasarkan asumsi dasar satuan uang (monetary unit assumption) yang menyatakan bahwa transaksi yang dapat dicatat dalam proses akuntansi hanyalah transaksi yang dinyatakan/ dapat diukur dalam satuan uang (Weygandt, et al. 2005). Berdasarkan asumsi tersebut, 
maka laporan keuangan yang disajikan oleh perusahaan secara umum hanya menggambarkan pengaruh keuangan dari kejadian di masa lalu dan tidak diwajibkan untuk menyediakan informasi nonkeuangan.

Banyak informasi penting yang selama ini bersifat non keuangan hanya dapat diungkapkan dalam laporan keuangan tetapi tidak dapat tercermin dalam neraca maupun laporan laba rugi. Kesepakatan yang telah dicapai dalam upaya mengurangi pemanasan global telah mendorong berkembangnya mekanisme perdagangan hak emisi karbon (carbon emission rights atau carbon emission permits atau emission allowance). Emisi karbon yang dihasilkan oleh aktivitas produksi dari industri, sebelumnya dikategorikan sebagai dampak negatif terhadap lingkungan (eksternalitas negatif). Eksternalitas negatif tersebut selama ini tidak dapat diakui/ dicatat dalam akuntansi keuangan karena tidak dapat dikuantifikasikan/ dinyatakan dalam satuan uang. Hal ini dalam perkembangannya dapat diatasi melalui pengenalan mekanisme perdagangan hak emisi karbon (Emissions Trading). Pada dasarnya mekanisme ini mengatasi masalah kesulitan pengakuan yang selama ini dihadapi melalui pengalokasian nilai uang terhadap hak emisi karbon yang diberikan oleh pemerintah atau pihak yang berwenang yang selanjutnya dapat diperjualbelikan oleh pemegang hak tersebut.

Perubahan dalam karakteristik eksternalitas negatif berupa hak emisi karbon menjadi aset tidak berwujud yang dapat diperjualbelikan telah mengatasi masalah pengakuan hak emisi karbon dalam akuntansi keuangan. Masalah yang diperdebatkan terkait dengan praktik perdagangan hak emisi karbon sejak 2003 adalah berhubungan dengan metode pencatatan dan penilaian yang digunakan. Hingga saat suatu kesepakatan tentang metode pencatatan dan penilaian yang dapat diterima secara konseptual maupun secara praktik belum ditentukan.

\section{KAJIAN PUSTAKA \\ Ekternalitas dan Pelaporan}

Berdasarkan PSAK No. 1 (IAI 2009). manajemen suatu entitas bertanggung jawab untuk menyajikan laporan keuangan yang terdiri dari Neraca, Laporan Laba Rugi, Laporan Perubahan Ekuitas, Laporan Arus Kas, dan Catatan Atas Laporan Keuangan. Laporan lainnya yang dianggap penting dapat pula disajikan oleh suatu entitas seperti laporan mengenai lingkungan hidup dan laporan nilai tambah. Namun demikian, PSAK ini tidak mewajibkan penyusunan informasi non keuangan dan hanya mengharuskan adanya pengungkapan informasi yang relevan agar laporan keuangan dapat disajikan secara wajar. Berdasarkan ketentuan ini maka informasi yang termasuk nonkeuangan dan juga tidak relevan terhadap kewajaran penyajian laporan keuangan akan diperlakukan sebagai laporan tambahan yang bersifat sukarela (voluntary).

Eksternalitas (externalities) didefinisikan sebagai dampak dari suatu kegiatan terhadap pihak lain dan pihak lain tersebut tidak diberi kompensasi dari atau tidak membayar dampak tersebut (Steinacker 2006: 462). Sesuai dengan definisi tersebut, Steinacker (2006: 462) menyatakan lebih lanjut bahwa dampak lingkungan yang 
bersifat negatif terjadi pada saat aktivitas yang dilakukan menyebabkan timbulnya kerugian pada pihak lain, seperti timbulnya polusi, limbah, dan pencemaran lainnya. Dalam hal ini dampak lingkungan tersebut sulit untuk dapat diukur dalam satuan uang karena pihak-pihak yang terkait tidak saling bertukar barang atau kas dan kejadian tersebut sering kali tidak memiliki dampak secara langsung terhadap pihakpihak yang terkait. Oleh karena itu akan sulit bagi akuntansi keuangan untuk mencatat kejadian tersebut dalam catatan-catatan akuntansi dampak negatif tersebut tidak dapat diukur dalam satuan uang. Kesulitan dalam pencatatan inilah yang menyebabkan eksternalitas negatif selama ini tidak tercermin dalam laporan keuangan tetapi hanya merupakan laporan nonkeuangan yang bersifat voluntary.

\section{Sejarah Timbulnya Mekanisme Perdagangan Emisi Karbon}

Konsep tentang perdagangan hak emisi karbon merupakan suatu hal yang relatif baru yang digunakan sebagai alat ekonomi untuk mewujudkan upaya menjaga kelestarian lingkungan (Ducsai, 2009). Dalam konsep tersebut diatur adanya kuota polusi atau batas jumlah emisi karbon yang diizinkan untuk setiap entitas yang berhak mendapatkan kuota. Entitas yang mendapatkan hak mengeluarkan emisi tersebut dapat menjual haknya jika mampu beroperasi dengan jumlah emisi gas di bawah kuota yang diizinkan. Sebaliknya entitas yang tidak mampu beroperasi sesuai dengan kuota emisi karbon yang ditetapkan dapat membeli tambahan hak untuk mengeluarkan emisi karbon tersebut dari entitas yang memiliki kelebihan kuota. Dengan demikian nantinya mekanisme kekuatan pasar akan berlaku, sehingga sesuai dengan prinsip dasar ekonomi, setiap entitas akan berupaya untuk mencari cara mempertahankan efisiensi biaya.

Dilihat dari aspek pengurangan dampak negatif terhadap lingkungan, jumlah total kuantitas hak emisi karbon yang ditetapkan dan selanjutnya didistribusikan oleh pemerintah atau pihak yang berwenang tidak akan meningkat sepanjang periode perdagangan hak emisi gas. Selain itu jumlah tersebut dalam jangka panjang akan dikurangi hingga mencapai target penurunan jumlah polusi secara global. Secara ekonomi hal ini akan mendorong penjual dan pembeli hak emisi karbon berupaya untuk memperoleh pendapatan atau melakukan penghematan biaya. Penjual akan mendapatkan laba dari penjualan per unit hak emisi karbon sedangkan pembeli berupaya menekan pengeluarannya dengan menekan pengeluaran polusinya. Oleh karena itu aktivitas ini dapat mendorong penurunan jumlah polusi yang dikeluarkan.

Protokol Kyoto merupakan kesepakatan (sejak 1997) yang memuat tentang perdagangan hak emisi karbon, dalam rangka mengatasi masalah pemanasan global. Negara-negara yang meratifikasi protokol ini berkomitmen untuk mengu-rangi emisi/ pengeluaran karbondioksida dan lima gas rumah kaca lainnya, atau bekerja sama dalam perdagangan hak emisi karbon dalam rangka menjaga jumlah atau mengendalikan emisi gas-gas yang berhubungan dengan pemanasan global. Protokol ini awalnya ditujukan untuk 37 negara industri maju yang beroperasi selama lebih dari 150 tahun dan paling bertanggung jawab atas tingginya emisi gas rumah kaca 
pada saat ini, namun pada 16 Februari 2005 sebanyak 141 negara telah meratifikasi protokol ini.

Protokol Kyoto menawarkan cara untuk mencapai target emisi gas rumah kaca secara efektif dan menguntungkan melalui mekanisme pasar, yaitu melalui perdagangan hak emisi karbon. Konsep perdagangan hak emisi karbon sebenarnya didasarkan pada penciptaan nilai melalui distribusi hak emisi karbon. Suatu negara dapat menjalankan mekanisme perdagangan hak emisi karbon ini dengan cara menetapkan jumlah total emisi karbon yang akan dikeluarkan selama periode kepatuhan (compliance period) sesuai dengan jumlah yang telah disepakati dalam Protokol Kyoto. Jumlah total emisi karbon yang telah ditetapkan tersebut selanjutnya didistribusikan ke berbagai entitas melalui alokasi hak emisi karbon/ cadangan pengeluaran emisi (allowances to emit). Masing-masing cadangan pengeluaran emisi memberikan hak untuk mengeluarkan 1 ton emisi $\mathrm{CO}_{2}$ atau gas rumah kaca lainnya. Sebagian besar hak emisi karbon diberikan oleh pemerintah melalui mekanisme perdagangan emisi karbon tanpa dipungut biaya atau gratis, tetapi jumlah yang diberikan ini biasanya lebih rendah dibandingkan dengan jumlah tingkat emisi yang sebenarnya dikeluarkan oleh entitas yang bersangkutan. Hal ini menyebabkan timbulnya kelangkaan yang mendorong proses penciptaan nilai bagi pemegang hak emisi karbon tersebut.

Hak emisi karbon dapat diperdagangkan secara domestik (antarperusahaan) maupun secara regional (antarnegara). Jumlah cadangan pengeluaran emisi yang diperdagangkan antarnegara dibatasi agar negara pembeli tetap memenuhi kewajibannya untuk menurunkan tingkat emisinya sesuai dengan kesepakatan dalam Protokol Kyoto (Kyoto Protocol Reference Manual). Mekanisme perdagangan emisi karbon ini (Emissions Trading) mulai berlaku di Uni Eropa yang dikenal dengan European Emission Trading Scheme (EU ETS) sejak Januari 2005 (Deegan, C. 2006: 361).

Perdagangan hak emisi karbon pada tingkat nasional merupakan cara mengurangi jumlah emisi karbon dengan cara yang cukup murah. Penerbitan peraturan tentang batas jumlah emisi karbon yang harus dipatuhi akan menyebabkan batas tersebut digunakan sebagai dasar pembebanan berbagai bentuk denda kepada perusahaan. Selain itu perdagangan hak emisi karbon akan mendorong perusahaan untuk memutuskan mana yang lebih menguntungkan, memproduksi produk pada tingkat harga emisi karbon pada saat itu atau terpaksa menutup aktivitas produksinya untuk memperbaiki fasilitas produksinya agar dapat memenuhi peraturan batas jumlah emisi (Ducsai: 2009). Berdasarkan hal tersebut, diharapkan aktivitas pencemaran udara dapat berkurang melalui pembebanan harga per unit polusi yang dikeluarkan.

\section{Perlakuan Akuntansi atas Perdagangan Emisi Karbon}

Permasalahan perlakuan akuntansi yang timbul terkait dengan metode penilaian dan pencatatan hak emisi karbon yang diberikan oleh pemerintah yang selanjutnya dapat diperdagangkan dan jika terdapat selisih dengan pemakaian sesungguhnya. 
Untuk mengatasinya, International Financial Reporting Interpretations Committee (IFRIC) berpedoman pada International Financial Reporting Standards (IFRS) yang sudah ada dengan cara menerbitkan interpretasi atas perlakuan terhadap mekanisme perdagangan hak emisi karbon. Upaya penerbitan draf interpretasi dilakukan 20022003 sebelum diluncurkannya EU ETS, tetapi draf ini masih memiliki kelemahan karena pada saat itu pedoman pelaksanaan perdagangan hak emisi karbon masih belum sempurna. Masalah yang terkait dengan perlakuan akuntansi perdagangan hak emisi karbon pada saat diluncurkannya draf tersebut adalah perlakuan pada saat jumlah cadangan pengeluaran emisi yang diberikan secara gratis oleh pemerintah sama dengan jumlah emisi karbon yang sesungguhnya dikeluarkan oleh suatu entitas dan entitas tersebut tidak menjualnya kepada pihak lain. Hal ini menyebabkan tidak adanya selisih/ nilai pertukaran yang dapat diakui sebagai laba bersih atau rugi bersih. Oleh karena itu pencatatan laba/rugi hanya dapat dilakukan jika terdapat selisih lebih (kurang) dari pema-kaian cadangan tersebut dan selisih ini diperdagangkan.

Berdasarkan IFRIC 3 yang diterbitkan pada akhir 2004, perlakuan akuntansi terhadap hak emisi karbon yang dialokasikan oleh pemerintah maupun yang diperoleh melalui pembelian diakui sebagai aset tidak berwujud menurut IAS 38 (Intangible Assets). Izin/ hak yang diberikan oleh pemerintah tanpa dipungut biaya merupakan bantuan pemerintah sehingga pada awalnya akan diakui sebagai aset tidak berwujud sebesar nilai wajar (fair value) dan akun lawannya adalah pendapatan tangguhan (deferred incomel credit) bantuan pemerintah sesuai dengan IAS 20 (Accounting for Government Grants and Disclosure of Government Assistance). Selanjutnya perusahaan dapat memilih untuk mencatat aset tidak berwujud tersebut sebesar biaya perolehan (at cost) atau nilai wajar (sepanjang pasar yang aktif untuk perdagangan izin tersebut ada). Selama tahun berjalan, setiap kali perusahaan mengeluarkan emisi gas, kewajiban akan diakui sesuai dengan kewajiban perusahaan untuk menjaga jumlah emisi gasnya sebanyak hak emisi karbon yang diberikan oleh pemerintah. Perlakuan akuntansi ini sesuai dengan IAS 37 tentang kewajiban diestimasi, kewajiban kontinjensi, dan aset kontinjensi (Provisions, Contingent Liabilities And Contingent Assets). Kewajiban ini diukur pada akhir periode pelaporan dengan menggunakan acuan nilai pasar yang berlaku. Selama tahun berjalan, perusahaan akan menghapuskan pendapatan tangguhan sebelumnya dan mengakui sebagai pendapatan secara sistematis di laporan laba rugi. Hak emisi karbon yang dicatat sebagai aset tidak berwujud, dihapuskan pada saat dijual ke pasar atau diserahkan kembali ke pemerintah pada saat pelunasan/ penyelesaian kewajiban untuk mengeluarkan emisi karbon sebesar hak yang diberikan/ dimiliki. Jika hak emisi karbon diperdagangkan di pasar yang aktif, maka hak emisi karbon tersebut tidak boleh diamortisasi.

Pendekatan biaya perolehan dan revaluasi menurut IFRIC 3 pada dasarnya membahas tentang pengakuan aset dan kewajiban yang berhubungan dengan mekanisme perdagangan emisi gas seperti EU ETS. Sebagaimana telah dijelaskan sebelumnya, IFRIC 3 menjelaskan tiga elemen dalam neraca yaitu aset tidak berwujud yang mencerminkan hak emisi karbon yang diperoleh secara cuma-cuma 
dari pemerintah atau melalui pembelian, kewajiban yang timbul dari pengeluaran emisi secara fisik yang jumlahnya sama dengan jumlah nilai dari hak yang telah diberikan dan harus diserahkan kembali pada akhir periode kepada pemerintah untuk memenuhi persyaratan pengeluaran emisi karbon, dan elemen pendapatan tangguhan (deferred income) yang mencatat bantuan pemerintah pada saat hak emisi gas diberikan secara cuma-cuma. Sehubungan dengan hak emisi gas sebagai suatu aset, untuk pencatatan pertama kali selalu diukur sebesar nilai wajar yang diterima. Setelah pengakuan dan pencatatan pertama kali dari penerimaan hak emisi karbon sebagai aset tidak berwujud, pengukuran untuk transaksi selanjutnya dapat menggunakan dua alternatif pilihan yaitu berdasarkan pendekatan biaya per-olehan atau menggunakan pendekatan revaluasi. Kedua alternatif tersebut akan melaporkan beban akibat penurunan harga pasar hak emisi karbon berdasarkan aturan lower of cost or market (mana yang lebih rendah antara biaya perolehan atau harga pasar). Perbedaan antara keduanya terjadi jika harga pasar naik sehingga menghasilkan selisih positif. Berdasarkan metode biaya perolehan, tidak ada keuntungan yang direalisasi sampai dengan hak emisi karbon tersebut dijual. Sedangkan metode revaluasi mengakui adanya surplus yang termasuk dalam ekuitas dan dicatat dalam akun surplus revaluasi. Nilai dari kewajiban dihitung dengan cara mengalikan jumlah hak emisi gas yang dibutuhkan dengan harga pasar yang berlaku pada saat itu dan jumlah kewajiban ini akan meningkat sejalan dengan peningkatan jumlah emisi yang digunakan. Pencatatan timbulnya kewajiban ini akan diimbangi dengan timbulnya beban sebesar nilai yang sama sesuai dengan jumlah hak emisi gas yang dibutuhkan untuk proses produksi. Elemen pendapatan tangguhan diakui sebesar nilai wajar pada saat bantuan pemerintah berupa hak emisi karbon diberikan untuk pertama kalinya. Selanjutnya pendapatan tangguhan ini diamortisasi secara sistematis dan diakui sebagai pendapatan yang selanjutnya disandingkan dengan perubahan dalam jumlah kewajiban emisi yang telah dicatat sebagai beban. Metode pencatatan seperti ini menimbulkan masalah ketidaksesuaian pada saat menerapkan matching principle di laporan laba rugi. Ketidaksesuaian (mismatch) dalam pelaporan ini akibat perbedaan perlakuan pengukuran dimana pengukuran aset (baik menggunakan metode biaya perolehan maupun revaluasi), pendapatan tangguhan (diamortisasi sebesar biaya perolehan), dan kewajiban (menggunakan nilai wajar) tidak konsisten sehingga menjadi tidak wajar jika diperbandingkan di laporan keuangan.

Penerapan IFRIC 3 mendapat penolakan akibat ada beberapa kelemahan prinsip yang menimbulkan ketidakseimbangan dalam akuntansi. Sebagaimana telah dijelaskan sebelumnya, kelemahan tersebut antara lain adalah dalam hal pengukuran aset dan kewajiban. Jika untuk pencatatan aset menggunakan pendekatan biaya perolehan sedangkan pencatatan kewajiban menggunakan nilai wajar, maka terjadi ketidakseimbangan dalam hal pengakuan aset dan kewajiban pada akhir periode pelaporan dimana kewajiban dan aset akan saling menghapuskan pada saat penyerahan hak emisi karbon sebagai pertanggungjawaban pengendalian pengeluaran emisi dari entitas kepada pemerintah. Kelemahan berikutnya terletak pada lokasi pelaporan dari timbulnya laba dan rugi dari transaksi aset dan kewajiban. Jika 
pendekatan nilai wajar digunakan untuk menilai aset, perubahan dari nilai aset akan diakui di posisi ekuitas sedangkan perubahan dari nilai kewajiban akan diakui dalam laporan laba rugi. Kelemahan yang terakhir terkait dengan ketidaksesuaian dalam hal periode pencatatan. Hak emisi karbon diakui pada saat diperoleh, biasanya di awal tahun, sedangkan kewajiban emisi diakui selama tahun berjalan secara sistematis pada saat terjadinya pengeluaran emisi gas dan dicatat sebesar nilai wajar pada saat terjadinya. Kelemahan-kelemahan inilah yang menyebabkan hanya sedikit perusahaan yang terlibat dalam mekanisme perdagangan emisi karbon menerapkan IFRIC 3 secara suka-rela. Akhirnya beberapa pendekatan diadopsi/ dikembangkan dalam praktik akuntansi untuk mengatasi kelemahan tersebut antara lain pendekatan kewajiban bersih (net liability) dan pendekatan bantuan pemerintah (government grant) (Ernst \& Young Global Limited, 2009).

Dalam pendekalan kewajiban bersih, hak emisi karbon diberikan pemerintah dicatat sebesar nilai nominal (yaitu 0 jika diberikan secara cuma-cuma) dan perusahaan hanya akan mencatat kewajiban pada saat emisi karbon sesungguhnya dikeluarkan telah melampaui hak emisi karbon yang telah diberikan oleh pemerintah. Berdasarkan pendekatan ini hak emisi karbon yang dibeli dicatat seperti halnya pembelian aset tidak berwujud lainnya.

Jika perusahaan menggunakan pendekatan pencatatan bantuan pemerintah sesuai IAS 20, maka hak emisi karbon yang diberikan pemerintah akan dicatat pertama kali sebesar nilai wajar dan akun lawannya adalah pendapatan tangguhan (deferred income) bantuan pemerintah di neraca. Selanjutnya pendapatan tangguhan ini akan dihapuskan secara sistematis dan diakui sebagai pendapatan selama periode efektif hak emisi karbon yang diberikan. Perlakuan akuntansi dengan pendekatan ini lebih mengikuti rekomendasi IFRIC 3, tetapi pencatatan kewajiban tidak diukur berdasarkan harga pasar yang yang berlaku pada saat penggunaan hak emisi karbon, melainkan berdasarkan jumlah nilai yang dicatat atas hak emisi karbon yang diakui sebagai aset tidak berwujud. Pada akhir periode efektif dari hak emisi karbon/ periode pelaporan nilai aset tidak berwujud dapat digunakan untuk menghapus kewajiban pada akhir periode pelaporan karena jumlah nilai dari kedua elemen tersebut sama. Ilustrasi penerapan ketiga pendekatan perlakuan akuntansi atas izin emisi karbon dijelaskan pada contoh kasus berikut (Ernst \& Young Global Limited, 2009: 5).

Perusahaan menerima hak emisi karbon pada 1 Januari 2009, yang memberikan hak untuk mengeluarkan emisi gas sebesar 10.000 ton emisi karbon untuk tahun yang berakhir 31 Desember 2009. Harga pasar untuk hak emisi karbon yang berlaku pada 1 Januari 2009 adalah $€ 10 /$ ton.

Data tentang harga pasar dan pengeluaran emisi karbon dapat dilihat pada tabel sebagai berikut: 
Tabel 1

Harga Pasar dan Pengeluaran Emisi Karbon

\begin{tabular}{ccc}
\hline Triwulan & Emisi Karbon & Harga pasar \\
\hline I & 3.000 ton & $€ 10 /$ ton \\
II & 3.000 ton & $€ 12 /$ ton \\
III & 3.000 ton & $€ 14 /$ ton \\
IV & 3.000 ton & $€ 16 /$ ton \\
\hline
\end{tabular}

Perbedaan dari penerapan berbagai alternatif pendekatan perlakuan akuntansi izin emisi karbon dapat dilihat pada tabel berikut:

Tabel 2

Penerapan Alternatif Pendekatan

\begin{tabular}{|c|c|c|c|}
\hline & $\begin{array}{l}\text { Pendekatan }^{1} \\
\text { IFRIC } 3\end{array}$ & $\begin{array}{c}\text { Pendekatan } \\
\text { Kewajiban Bersih }\end{array}$ & $\begin{array}{c}\text { Pendekatan Bantuan } \\
\text { Pemerintah }\end{array}$ \\
\hline $\begin{array}{l}\text { Pengakuan Aset Tidak } \\
\text { Berwujud } 1 \text { Januari } 2009\end{array}$ & $\begin{array}{c}€ 100.000 \\
(10.000 \times € 10)\end{array}$ & $€ 0$ & $\begin{array}{c}€ 100.000 \\
(10.000 \times € 10)\end{array}$ \\
\hline Trw. I saldo Kewajiban & $\begin{array}{c}€ 30.000 \\
(3.000 \times € 10)\end{array}$ & $€ 0$ & $\begin{array}{c}€ 30.000 \\
(3.000 \times € 10)\end{array}$ \\
\hline Trw. II saldo Kewajiban & $\begin{array}{c}€ 72.000 \\
(6.000 \times € 12)\end{array}$ & $€ 0$ & $\begin{array}{c}€ 60.000 \\
(6.000 \times € 10)\end{array}$ \\
\hline Trw. III saldo Kewajiban & $\begin{array}{c}€ 126.000 \\
(9.000 \times € 14)\end{array}$ & $€ 0$ & $\begin{array}{c}€ 90.000 \\
(9.000 \times € 10) \\
€ 132.000\end{array}$ \\
\hline Trw. IV saldo Kewajiban & $\begin{array}{c}€ 192.000 \\
(12.000 \times € 16)\end{array}$ & $\begin{array}{c}€ 32.000 \\
(2.000 \times € 16)\end{array}$ & $\begin{array}{c}(10.000 \times € 10) \\
\text { ditambah } \\
(2.000 \times € 16)\end{array}$ \\
\hline Total Biaya 2009 & $€ 192.000$ & $€ 32.000$ & $€ 132.000$ \\
\hline Total Pendapatan 2009 & $€ 100.000$ & $€ 0$ & $€ 100.000^{2}$ \\
\hline
\end{tabular}

${ }^{1}$ Dengan asumsi pendekatan revaluasi dalam IAS 38 tidak diadopsi.

2 Menjadi penghapus pendapatan tangguhan (bantuan pemerintah) di laporan laba rugi.

Berdasarkan perbandingan dengan asumsi bahwa pendekatan IFRIC 3 yang digunakan adalah metode biaya perolehan, setelah pengakuan penerimaan hak emisi karbon dari pemerintah, maka metode ini akan menghasilkan ketidaksesuaian jumlah yang diperbandingkan antara beban dan pendapatan (dari perolehan hak emisi gas secara gratis dan dinilai sebesar nilai wajar). Nilai yang dihasilkan akibat ketidaksesuaian pengukuran aset dan kewajiban mencapai €60.000 (€6 x 10.000) yang disebabkan oleh perubahan nilai kewajiban yang diukur pada nilai wajar dan bukan disebabkan oleh pembelian tambahan hak emisi karbon untuk menutup kekurangan pengeluaran emisi karbon. Sebaliknya jika menggunakan metode pendekatan kewajiban bersih dan pendekatan pencatatan bantuan pemerintah, maka selisih beban dan pendapatan yang tercatat adalah sebesar pembelian tambahan hak 
emisi karbon untuk menutup kekurangan pengeluaran emisi karbon. Kedua metode terakhir ini tidak menunjukkan adanya ketidaksesuaian dalam pengukuran pendapatan dan beban karena hanya mencatat tambahan hak emisi karbon sesuai dengan nilai wajar dan pembebanan emisi karbon juga dihitung berdasarkan nilai wajar perolehan awal.

Jika menggunakan pendekatan IFRIC 3 metode revaluasi (IAS 38 dengan asumsi terdapat pasar aktif untuk perdagangan hak emisi karbon), maka setiap terjadi kenaikan harga dari hak emisi karbon, akan diakui sebagai surplus revaluasi dan nilai aset tersebut akan dicatat sebesar harga pasar. Sedangkan metode biaya perolehan tidak akan mengakui adanya keuntungan akibat kenaikan harga sampai dengan hak emisi karbon tersebut dijual atau diserahkan kembali kepada pemerintah pada saat penyelesaian kewajiban emisi karbon. Kedua metode tersebut tetap akan menyebabkan ketidaksesuaian dalam pengukuran pendapatan dan beban yang disebabkan oleh beban yang diukur pada nilai wajar dan pendapatan yang diukur sesuai biaya perolehan.

U.S. GAAP (USofA 101.21) merupakan standar yang dibuat di Amerika untuk program emisi yang berbeda yaitu the Acid Rain Program as a part of the Clean Air Act Amendments of 1990 tetapi mengandung materi perlakuan akuntansi yang secara kualitatif sama. USofA 101.21 memuat prinsip yang sederhana yaitu: (1) hak emisi karbon dicatat sebesar biaya perolehan, (2) aset hanya dicatat untuk hak emisi karbon yang diperoleh melalui pembelian, dan (3) hak emisi karbon yang diperoleh secara gratis tidak dimasukkan dalam akuntansi keuangan. Hal ini berarti bahwa hak emisi hanya diakui pada saat dimiliki dengan tujuan untuk dijual (diklasifikasikan sebagai investasi lainnya) maupun untuk memenuhi kewajiban emisi karbon yang jumlahnya biasanya lebih tinggi dibandingkan dengan hak emisi karbon yang diberikan berdasarkan peraturan (diklasifikasikan sebagai persediaan). Harga pasar merupakan dasar pengukuran awal. Sepanjang tahun, hak emisi karbon yang dibeli dicatat sebesar harga perolehan dan didepresiasi sebesar jumlah yang digunakan. Jika entitas tidak memiliki jumlah hak emisi karbon sebesar nilai kebutuhan yang diestimasikan, maka kewajiban yang mencerminkan kekurangan hak emisi karbon dicatat sebesar harga pasar. Hal ini akan berdampak pada pendapatan saat perusahaan membeli tambahan hak emisi karbon dan menangguhkan pengakuan beban sampai dengan hak tersebut digunakan. Risiko terjadinya ketidaksesuaian dalam perlakuan akuntansi antara aset yang diukur berdasarkan biaya perolehan (at cost) dan kewajiban yang diukur berdasarkan nilai wajar tetap ada tetapi kecil, yaitu terjadi hanya pada saat perusahaan membeli hak emisi gas untuk menutup kekurangan hak emisi karbon yang telah diestimasikan sebelumnya, amortisasi aset dan revaluasi kewajiban akan memengaruhi laporan laba rugi secara asimetris.

Amandemen IAS 38 yang diusulkan IFRIC 3 sejak akhir 2003, dilakukan dengan menambahkan kategori ketiga dalam aset tak berwujud. Amandemen ini akan menyebabkan pengakuan perubahan nilai wajar dari aset secara langsung melalui laba dan rugi, mengurangi ketidaksesuaian antara ketiga elemen neraca (aset hak emisi karbon, kewajiban emisi karbon, bantuan pemerintah), dan dampak dari perubahan 
nilainya terhadap pendapatan. Walaupun perlakuan ini akan menyamakan metode pengukuran aset dan kewajiban emisi karbon, jumlah kuantitas hak emisi karbon yang dimiliki dan yang dikeluarkan masih berbeda. Selain itu, pengukuran bantuan pemerintah tetap tidak dibahas sehingga ketidak-sesuaian dalam pengukuran dan pelaporan kewajiban tetap terjadi. Usulan IFRIC tersebut tidak bermaksud untuk menyajikan pendekatan baru bagi perlakuan atas pendapatan tangguhan mengingat IAS 20 (Accounting for Government Grants and Disclosure of Government Grants) sedang dalam revisi.

Pada praktiknya, perusahaan-perusahaan go public di Uni Eropa menggunakan prinsip akuntansi yang dinyatakan dalam IFRS atau US GAAP serta aturan pengungkapan sejak EU ETS diluncurkan tahun 2005, karena prinsip akuntansi yang berlaku umum untuk perdagangan hak emisi gas belum ada. IFRIC 3 tentang hak emisi karbon yang semula diadopsi pada Desember 2004 pada akhirnya ditarik di tahun 2005. Hal ini terjadi akibat kegagalan IFRIC untuk merekomendasikan suatu perlakuan akuntansi yang pasti berdasarkan standar yang sudah ada dalam IFRS. Saat ini beberapa pendekatan perlakuan akuntansi digunakan dalam praktik akuntansi perdagangan perdagangan hak emisi gas. Beberapa perusahaan masih mengikuti interpretasi dalam IFRIC 3 dan menerapkan pendekatan biaya perolehan atau pendekatan revaluasi. Sedangkan beberapa perusahaan lainnya mengikuti rekomendasi dari Fédération des Experts Comptables Euro-péens (FEE-Federation of European Accountants) yang merujuk pada U.S. GAAP yang dikembangkan untuk emisi yang diatur dalam United States Clean Air Act Amendments of 1990 (Veith, et. al. 2009).

Berikut ini ilustrasi yang menggambarkan interaksi antarberbagai elemen di neraca dan laporan laba rugi yang memfokuskan pada dampak perubahan harga hak emisi karbon di laporan interim dalam satu tahun buku (Veith, et al. 2009 dan Cook 2008). Pengaruh fluktuasi harga dan pengaruh penyelesaian kewajiban yang jatuh pada awal tahun buku berikutnya disajikan. Ilustrasi ini juga menyajikan metode nilai wajar sebagaimana yang digambarkan di IASB dan juga pendekatan dalam USofA 101.21.

Ilustrasi ini mengasumsikan bahwa hak emisi karbon untuk siklus satu tahun akan dicatat di neraca mulai 1 Januari hingga 31 Desember. Namun demikian karena mekanisme EU ETS menghapuskan kewajiban dan aset untuk satu tahun buku tersebut setiap 30 April tahun berikutnya, maka ilustrasi ini juga akan menggambarkan seluruh akun pada tanggal neraca interim pertama di tahun berikutnya. Pada awalnya, perusahaan-perusahaan diberi hak emisi karbon seba-nyak 12.000 ton $\mathrm{CO}_{2}$ dengan harga $€ 10$ per ton. Enam bulan kemudian, 5.500 ton $\mathrm{CO}_{2}$ telah dikeluarkan; hak emisi karbon pada saat itu dijual pada harga €12 per ton. Pada akhir tahun, 12.500 ton $\mathrm{CO}_{2}$ telah dikeluarkan; hak emisi karbon pada saat itu dijual pada harga $€ 11$ per ton. Kekurangan sebanyak 500 ton hak emisi karbon ditutup pada 31 Desember. Pada kuartal pertama tahun berikutnya, diasumsikan emisi tahun sebelumya dan perubahan harga hak emisi karbon diabaikan. 


\section{Tabel 3}

IFRIC 3: Metode Revaluasi

\begin{tabular}{|c|c|c|c|c|}
\hline \multicolumn{5}{|l|}{ PANEL A: Neraca } \\
\hline & Alokasi & Interim & Akhir Tahun & Interim \\
\hline \multicolumn{5}{|l|}{ Aset } \\
\hline Hak Emisi Karbon & 120.000 & 144.000 & 137.500 & 0 \\
\hline \multirow[t]{2}{*}{ Kas } & 0 & 0 & -5.500 & -5.500 \\
\hline & 120.000 & 144.000 & 132.000 & -5.500 \\
\hline \multicolumn{5}{|l|}{ Kewajiban } \\
\hline Kewajiban/Utang & 0 & 66.000 & 137.500 & 0 \\
\hline $\begin{array}{l}\text { Pendapatan tangguhan - } \\
\text { Bantuan Pemerintah }\end{array}$ & 120.000 & 65.000 & 0 & 0 \\
\hline \multicolumn{5}{|l|}{ Modal } \\
\hline Surplus Revaluasi & 0 & 24.000 & 12.000 & 12.000 \\
\hline \multirow{2}{*}{ Laba Ditahan } & 0 & -11.000 & -17.500 & -17.500 \\
\hline & 120.000 & 144.000 & 132.000 & -5.500 \\
\hline \multicolumn{5}{|c|}{ PANEL B: LAPORAN LABA RUGI } \\
\hline & $\frac{\text { Setengah Tahun }}{\underline{\text { Pertama }}}$ & $\frac{\text { Setengah Tahun }}{\underline{\text { Kedua }}}$ & $\frac{\text { Satu Tahun }}{\underline{\text { Penuh }}}$ & $\frac{\text { Setengah Tahun }}{\underline{\text { Pertama }}}$ \\
\hline $\begin{array}{l}\text { Amortisasi dari } \\
\text { Pendapatan Tangguhan } \\
\text { - Bantuan Pemerintah }\end{array}$ & 55.000 & 65.000 & 120.000 & 0 \\
\hline Beban Emisi Gas & -66.000 & -71.500 & -137.500 & 0 \\
\hline Laba/Rugi & -11.000 & -6.500 & -17.500 & $\mathbf{0}$ \\
\hline
\end{tabular}

Harga hak emisi karbon turun pada setengah tahun kedua dalam contoh tersebut, dari $€ 12$ ke $€ 11$. Sekali lagi, terdapat selisih negatif pada pendapatan yang totalnya mencapai $€ 6.500$. Sejumlah $€ 5.500$ disebabkan oleh tambahan kewajiban emisi (polusi yang melebihi hak emisi karbon yang diberikan adalah sebanyak 500 ton, dengan harga pasar $€ 11 /$ ton pada akhir tahun). Sisanya sebesar $€ 1.000$ disebabkan oleh perbedaan metode pengukuran yang digunakan untuk mengukur kewajiban (berdasarkan nilai wajar) dan pendapatan tangguhan bantuan pemerintah (berdasarkan biaya perolehan). Pada tanggal jatuh tempo penghapusan seluruh aset dan kewajiban, yaitu 30 April, tidak ada pengaruh atas laba rugi yang terjadi.

\section{Tabel 4}

\section{IFRIC 3: Metode Biaya Perolehan}

\begin{tabular}{|c|c|c|c|c|}
\hline \multicolumn{5}{|l|}{ PANEL A: Neraca } \\
\hline & Alokasi & Interim & Akhir Tahun & Interim \\
\hline \multicolumn{5}{|l|}{ Aset } \\
\hline Hak Emisi Karbon & 120.000 & 120.000 & 125.500 & 0 \\
\hline \multirow[t]{2}{*}{ Kas } & 0 & 0 & -5.500 & -5.500 \\
\hline & 120.000 & 120.000 & 120.000 & -5.500 \\
\hline \multicolumn{5}{|l|}{ Kewajiban } \\
\hline Kewajiban/Utang & 0 & 66.000 & 137.500 & 0 \\
\hline $\begin{array}{l}\text { Pendapatan Tangguhan - } \\
\text { Bantuan Pemerintah }\end{array}$ & 120.000 & 65.000 & 0 & 0 \\
\hline \multicolumn{5}{|l|}{ Modal } \\
\hline \multirow[t]{2}{*}{ Laba Ditahan } & 0 & -11.000 & -17.500 & -5.500 \\
\hline & 120.000 & 120.000 & 120.000 & $\mathbf{0}$ \\
\hline
\end{tabular}




\section{PANEL B: LAPORAN}

LABA RUGI

\begin{tabular}{|c|c|c|c|c|}
\hline & $\frac{\text { Setengah Tahun }}{\underline{\text { Pertama }}}$ & $\frac{\text { Setengah Tahun }}{\underline{\text { Kedua }}}$ & $\underline{\text { Satu Tahun Penuh }}$ & 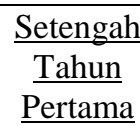 \\
\hline $\begin{array}{l}\text { Keuntungan dari } \\
\text { penyerahan } \\
\text { Hak Emisi Karbon }\end{array}$ & & 0 & 0 & 12.000 \\
\hline Amortisasi dari & & & & \\
\hline $\begin{array}{l}\text { Pendapatan tangguhan - } \\
\text { Bantuan Pemerintah }\end{array}$ & 55.000 & 65.000 & 120.000 & 0 \\
\hline Beban Emisi Gas & -66.000 & -71.500 & -137.500 & 0 \\
\hline Laba/Rugi & -11.000 & -6.500 & -17.500 & 12.000 \\
\hline
\end{tabular}

Sebagaimana dapat dilihat di tabel, penerapan metode biaya perolehan dibandingkan revaluasi tidak menyebabkan timbulnya perubahan kewajiban emisi karbon, tetapi hanya pada penilaian aset hak emisi karbon yang dinilai berdasarkan biaya perolehan atau harga pasar. Hal ini tidak menyebabkan penyesuaian terhadap pendapatan pada tahun berjalan tetapi penghapusan hak emisi karbon pada akhir periode akan menyebabkan ditampilkannnya keuntungan yang direalisasi akibat kenaikan harga pada saat penghapusan aset dan kewajiban. Dalam mekanisme perdagangan EU ETS, penghapusan dilakukan di laporan keuangan tahun berikutnya.yaitu pada 30 April.

Metode Full Fair Value (IASB, 2005)

Metode Full Fair Value terhadap perlakuan atas aset akan menghasilkan pengaruh di neraca dan laba rugi sebagaiman dapat dilihat di tabel berikut:

Tabel 5

Laporan Neraca dan Laba-Rugi

\begin{tabular}{lcccc}
\hline PANEL A: Neraca & & & & \\
\hline & $\underline{\text { Alokasi }}$ & $\underline{\text { Interim }}$ & $\underline{\text { Akhir Tahun }}$ & $\underline{\text { Interim }}$ \\
Aset & & & & \\
Hak Emisi Karbon & 120.000 & 144.000 & 137.500 & 0 \\
Kas & 0 & 0 & -5.500 & -5.500 \\
\cline { 2 - 5 } & $\mathbf{1 2 0 . 0 0 0}$ & $\mathbf{1 4 4 . 0 0 0}$ & $\mathbf{1 3 2 . 0 0 0}$ & $\mathbf{- 5 . 5 0 0}$ \\
Kewajiban & 0 & 66.000 & 137.500 & 0 \\
Kewajiban/Utang & 120.000 & 65.000 & 0 & 0 \\
$\begin{array}{l}\text { Pendapatan tangguhan } \\
\text { Bantuan Pemerintah }\end{array}$ & & & & \\
$\begin{array}{l}\text { Modal } \\
\text { Laba Ditahan }\end{array}$ & 0 & 13.000 & -5.500 & $\mathbf{- 5 . 5 0 0}$ \\
\cline { 2 - 5 } & $\mathbf{1 2 0 . 0 0 0}$ & $\mathbf{1 4 4 . 0 0 0}$ & $\mathbf{1 3 2 . 0 0 0}$ & $\mathbf{- 5 . 5 0 0}$
\end{tabular}




\section{PANEL B: LAPORAN}

LABA RUGI

\begin{tabular}{|c|c|c|c|c|}
\hline & $\frac{\text { Setengah Tahun }}{\underline{\text { Pertama }}}$ & $\frac{\text { Setengah Tahun }}{\underline{\text { Kedua }}}$ & $\underline{\text { Satu Tahun Penuh }}$ & $\frac{\text { Setengah }}{\text { Tahun }}$ \\
\hline Revaluasi Aset & 24.000 & -12.000 & 12.000 & 0 \\
\hline $\begin{array}{l}\text { Amortisasi Pendapatan } \\
\text { tangguhan -Bantuan } \\
\text { Pemerintah }\end{array}$ & 55.000 & 65.000 & 120.000 & 0 \\
\hline Beban Emisi Gas & -66.000 & -71.500 & -137.500 & 0 \\
\hline Laba/Rugi & 13.000 & -18.500 & -5.500 & $\mathbf{0}$ \\
\hline
\end{tabular}

Karakteristik dari metode ini menyatakan bahwa revaluasi positif dari aset berupa hak emisi karbon akan dibukukan di laporan laba atau rugi sehingga menghasilkan nilai bersih pendapatan dari mekanisme ETS dalam satu tahun buku sama dengan jumlah pengeluaran tambahan untuk mendapatkan cadangan yaitu sebesar $€ 5.500$. Namun demikian, berbagai perubahan akan tetap ada sepanjang tahun buku yang disebabkan oleh ketidahsesuaian dalam perlakuan akuntansi maupun pengukuran atas ketiga elemen.

\section{Metode USofA 101.21}

Tabel berikut menggambarkan perbedaan yang cukup material sesuai dengan penerapan U.S. GAAP. Pada saat akhir tahun buku, jumlah hak emisi karbon yang dibeli adalah sebesar $€ 5.500$. Karena tidak ada kerugian yang perlu dilaporkan, tidak ada kewajiban yang perlu diakui, dan hak emisi karbon dihapuskan selama periode waktu yang tersisa hingga saat jatuh tempo yaitu akhir tahun dari periode perdagangan hak emisi gas. Amortisasi sebesar jumlah kas yang dikeluarkan diakui pada periode pelaporan interim di tahun berikutnya.

Tabel 6

Laporan Neraca dan Laba-Rugi

\begin{tabular}{|c|c|c|c|c|}
\hline \multicolumn{5}{|l|}{ PANEL A: Neraca } \\
\hline & Alokasi & $\underline{\text { Interim }}$ & Akhir Tahun & Interim \\
\hline \multicolumn{5}{|l|}{ Aset } \\
\hline Hak Emisi Karbon & 0 & 0 & 5.500 & 0 \\
\hline \multirow[t]{2}{*}{ Kas } & 0 & 0 & -5.500 & -5.500 \\
\hline & $\mathbf{0}$ & $\mathbf{0}$ & $\mathbf{0}$ & -5.500 \\
\hline \multicolumn{5}{|l|}{ Kewajiban } \\
\hline Provisi & 0 & 0 & 0 & 0 \\
\hline \multicolumn{5}{|l|}{ Modal } \\
\hline \multirow[t]{2}{*}{ Laba Ditahan } & 0 & 0 & 0 & -5.500 \\
\hline & $\mathbf{0}$ & $\mathbf{0}$ & $\mathbf{0}$ & -5.500 \\
\hline
\end{tabular}




\begin{tabular}{|c|c|c|c|c|}
\hline \multicolumn{5}{|l|}{$\begin{array}{l}\text { PANEL B: LAPORAN } \\
\text { LABA RUGI }\end{array}$} \\
\hline & $\frac{\text { Setengah Tahun }}{\underline{\text { Pertama }}}$ & $\frac{\text { Setengah Tahun }}{\underline{\text { Pertama }}}$ & $\underline{\text { Satu Tahun Penuh }}$ & $\frac{\text { Setengah }}{\frac{\text { Tahun }}{\text { Pertama }}}$ \\
\hline \multirow{3}{*}{$\begin{array}{l}\text { Amortisasi dari Hak Emi } \\
\text { Perubahan Nilai Provisi } \\
\text { Laba/Rugi }\end{array}$} & Karbon & & & \\
\hline & 0 & 0 & 0 & 0 \\
\hline & 0 & 0 & 0 & -5.500 \\
\hline
\end{tabular}

\section{SIMPULAN}

Jika menggunakan pendekatan IFRIC 3 untuk melaporkan hak emisi karbon, maka pada kondisi sederhana dimana harga tidak berubah/ konstan, maka tidak ada dampaknya terhadap laba rugi perusahaan untuk setiap tanggal neraca. Amortisasi pendapatan tangguhan dibandingkan dengan perubahan kewajiban akan menunjukkan nilai yang sama, demikian juga aset dan kewajiban akan bernilai sama pada akhir periode perdagangan sehingga dapat saling menghapuskan. Sebaliknya jika terjadi fluktuasi harga dan terdapat pasar yang aktif untuk hak emisi karbon, maka pendekatan nilai wajar harus digunakan. Namun pendekatan nilai wajar yang rekomendasikan IFRIC 3 maupun Full Fair Value tetap menghasilkan ketidaksesuaian pengukuran antara beban dan pendapatan. Hal ini terjadi akibat penerapan IAS 20 yang menghapuskan pendapatan tangguhan sebesar biaya perolehan secara sistematis yang diimbangi dengan pengakuan beban sebesar nilai wajar. Jika IAS 20 tidak di revisi terkait dengan pencatatan transaksi hak emisi karbon dengan metode nilai wajar, maka upaya IFRIC 3 untuk menyelaraskan 3 standar (IAS 37, 38 dan 20) tetap memiliki kelemahan prinsip. IASB telah berupaya untuk memperbaiki kelemahan tersebut hingga akhir 2009 dan Exposure Draft dari perbaikan model akuntansi yang direkomendasikan diharapkan dapat diterbitkan pada kuartal kedua 2010. Secara substansi sebenarnya karakteristik transaksi hak emisi karbon memang menggabungkan ketiga standar yang telah dijelaskan sebelumnya, tetapi jika seandainya revisi terhadap IAS 20 maupun IAS 37 dan 38 akan mengakibatkan interpretasi terhadap perlakuan akuntansi dari transaksi lain-nya menjadi bias, maka sebaiknya diterbitkan standar tersendiri. Perlakuan akuntansi yang lebih sederhana dan tidak menimbulkan ketidaksesuaian dalam peng-ukuran beban dan pendapatan dapat diadopsi untuk meminimalkan salah saji yang material dari aspek jumlah pendapatan yang dilaporkan. Dalam hal ini pendekatan kewajiban bersih, pendekatan bantuan pemerintah, dan U.S. GAAP (USofA 101.21) dapat diadopsi untuk sementara waktu hingga standar yang pasti dike-luarkan. Walaupun metode-metode tersebut tidak menggambarkan substansi dari transaksi hak emisi karbon sesuai dengan perubahan nilai wajar, tetapi metode ini tidak menghasilkan salah saji yang dapat menyebabkan interpretasi yang salah terhadap pendapatan dan beban. 


\section{DAFTAR PUSTAKA}

An Operator's Guide to the EU Emissions Trading Scheme (Online)

(http://www.defra.gov.uk/environment/climatechange/trading/eu/intro/euetsguide.pdf diakses 1 Oktober 2009).

Cook, A. 2008. "Emission rights: From costless activity to market operations," Accounting Organizations and Society (Online). (http://www.china-sds.org/kcxfzbg/addinfomanage/rdgz/data/wps1.pdf diakses 2 Oktober 2009).

CPA Australia Ltd. 2008. "IAS 38 Intangible assets," International Financial Reporting Standards - Fact Sheet (Online). (http://www.cpaaustralia.com.au/cps/rde/xbcr/SID-3F57FECAE86E3E39/cpa/fact_sheet_IAS38_220408.pdf diakses 2 Oktober 2009)..

Cummings, L., Dyball, M. D., \& Pang, C. 2009, “Accounting for Carbon,” Intheblack (Online), Vol. 79, No.07,(http://www.cpaaustralia.com.au/cps/rde/xchg/SID3F57FECB-2424B3A4/cpa/hs.xsl/724_32490_ENA_HTML.htm diakses 2 Oktober 2009).

Deegan, C. 2006. Financial Accounting Theory, 2nd ed. Sydney: McGraw-Hill Irwin.

Deloitte Development LLC. 2007. Accounting for Emission Rights (Online), (http://www.deloitte.com/assets/Dcom-

Australia/Local\%20Assets/Documents/Deloitte_Accounting_Emissionright_Feb 07.pdf diakses 2 Oktober 2009).

Deloitte Touche Tohmatsu Ltd. 2008. Australian emissions trading scheme Accounting for emission rights (Online), (http://www.deloitte.com/assets/DcomAustralia/Local\%20Assets/Documents/Emissions_trading_scheme.pdf diakses 2 Oktober 2009).

Deloitte Touche Tohmatsu. 2009. "IASB Agenda Project - Emissions Trading Schemes", IAS Plus (Online), (http://www.iasplus.com/agenda/emissiontrading.htm diakses 2 Oktober 2009).

Deloitte Touche Tohmatsu. 2009. "IFRIC 3 Emission Rights - The IASB withdrew IFRIC 3 at its meeting in June 2005," IAS Plus (Online), (http://www.iasplus.com/interps/ifric003.htm diakses 2 Oktober 2009).

Deloitte Touche Tohmatsu. 2009. "Summaries of International Financial Standards IAS 38 Intangible Assets," IAS Plus (Online), (http://www.iasplus.com/standard/ias38.htm diakses 2 Oktober 2009).

Deloitte Touche Tohmatsu. 2009. "Summaries of International Financial Standards IAS 37 Provisions, Contingent Liabilities and Contingent Assets," IAS Plus (Online), (http://www.iasplus.com/standard/ias37.htm diakses 2 Oktober 2009). Deloitte Touche Tohmatsu. 2009. "Summaries of International Financial Standards IAS 20 Accounting for Government Grants And Disclosure of Government Assistance," IAS Plus (Online), (http://www.iasplus.com/standard/ias37.htm diakses 2 Oktober 2009). 
Directive 2003/87/EC of the European Parliament and of the Council (Online), (http://eurlex.europa.eu/LexUriServ/LexUriServ.do?uri=CELEX:32003L0087:EN:HTML diakses 1 Oktober 2009).

Ducsai, A. R. 2007. “Accounting for emission rights," Social and Management Sciences (Online), Vol. 15, No: (53-57). (http://www.pp.bme.hu/so/2007_2/pdf/so2007_2_02.pdf diakses 2 Oktober 2009).

Ernst \& Young Global Limited. 2009. Accounting for Emission Reductions and Other Incentive Schemes (Online), (http://www.ey.com/Publication/vwLUAssets/Accounting_emission_reductions/ \$FILE/Accounting_emission_reductions_July09.pdf diakses 2 Oktober 2009).

Financial Accounting Standards Board. 2009. "Emissions Trading Schemes," Project Updates (Online), (http://www.fasb.org/emissions_trading_schemes.shtml diakses 2 Oktober 2009).

Fornaro, J. M., Winkelman, K. A., \& Goldstein D. 2009. “Accounting for Emissions". Journal of Accountancy (Online), (http://www.journalofaccountancy.com/Issues/2009/Jul/20081312.htm diakses 2 Oktober 2009).

Fornaro, J. M., Winkelman, K. A., \& Goldstein D. 2009. “Accounting for Emissions". Journal of Accountancy (Online), (http://www.journalofaccountancy.com/Issues/2009/Jul/20081312.htm diakses 2 Oktober 2009).

IASC Foundation Education 2009, "IAS 37 Provisions, Contingent Liabilities and Contingent Assets," Technical Summary (Online). (http://www.iasb.org/NR/rdonlyres/94C8F2F5-FC68-43E5-86AC211C9B701FE5/0/IAS37.pdf diakses 2 Oktober 2009).

IASC Foundation Education 2009, "IAS 38 Intangible Assets," Technical Summary (Online). (http://www.iasb.org/NR/rdonlyres/8A3C6720-AABE-4BE2-B7760BBE51961AA0/0/IAS38.pdf diakses 2 Oktober 2009).

IASC Foundation Education, "IAS 20 Accounting for Government Grants and Disclosure of Government Assistance," Technical Summary (Online). (http://www.iasb.org/NR/rdonlyres/38AE3001-72F2-4B2C-BB725930AF20BBF6/0/IAS20.pdf diakses 2 Oktober 2009).

IASC Foundation Education, "IAS 37 Provisions, Contingent Liabilities and Contingent Assets," Technical Summary (Online). (http://www.iasb.org/NR/rdonlyres/81F90956-3009-4346-B72711119816C992/0/IAS37.pdf diakses 2 Oktober 2009).

IASC Foundation Education, "IAS 38 Intangible Assets," Technical Summary (Online). (http://www.iasb.org/NR/rdonlyres/149D67E2-6769-4E8F-976D6BABEB783D90/0/IAS38.pdf diakses 2 Oktober 2009).

Ikatan Akuntan Indonesia (IAI). 2009. Standar Akuntansi Keuangan Per 1 Juli 2009, Jakarta: Salemba Empat 
International Accounting Standards Board. 2007. "Reproduction of September 2005 Agenda Proposal (Agenda Paper 5B(i))," Accounting for Emissions Trading Schemes (Online). (http://www.iasb.org/NR/rdonlyres/943F9432-1E2B-4C36A9DF-141B647FC1A7/0/AP0712b05biobs.pdf diakses 2 Oktober 2009).

International Accounting Standards Board. 2009. Emissions Trading Schemes (Online).

(http://www.iasb.org/Current+Projects/IASB+Projects/Emission+Trading+Sche mes/Emission+Trading+Schemes.htm diakses 2 Oktober 2009).

International Accounting Standards Committee. 2008. Emission Trading Schemes (Online). (http://www.iasb.org/NR/rdonlyres/D0D0B44A-254A-4112-9FCE34178B236D07/0/0811ProjectUpdateETSproject.pdf diakses 2 Oktober 2009).

Laidier, S L, \& Olsen, T. 2009. "Treatment of Emission Permits - Implications for the SEEA", Paper prepared for discussion at the 14th meeting of the London Group on Environmental Accounting (Online), (http://www.docstoc.com/docs/DownloadDoc.aspx?doc id=6328735 diakses 2 Oktober 2009).

Lam, N, \& Lau, P. 2009. Intermediate Financial Reporting an IFRS Perspektive. McGraw-Hill Education Asia.

Olsen, T. 2008. Emission permits (Online), (http://unstats.un.org/unsd/nationalaccount/AEG/papers/m6emissionadd1.pdf diakses 2 Oktober 2009).

Peterson, S. 2003. "Monitoring, Accounting and Enforcement in Emissions Trading Regimes," OECD Global Forum on Sustainable Development: Emissions trading (Online). (http://www.oecd.org/dataoecd/11/56/2957646.pdf diakses 2 Oktober 2009).

Shaltegger, S. \& Burritt, R. 2000. Contemporary Environmental Accounting: Issues, Concepts And Practice. Sheffield, Greenleaf Publishing Limited.

Steinacker, A. 2006. "Externalities, Prospect Theory, and Social Construction: When Will Government Act, What Will Government Do?", Social Science Quarterly, Vol.87, No.3.

Trottman, K, \& Gibbins, M. 2005. Financial Accounting: an Integrated Approach, $3^{\text {rd }}$ ed. Nelson Australia Pty Limited.

Trottman, K, \& Gibbins, M. 2005. Financial Accounting: an Integrated Approach, $3^{\text {rd }}$ ed. Nelson Australia Pty Limited.

Undang-Undang Republik Indonesia Nomor 17 Tahun 2004 tentang Pengesahan Kyoto Protocol To The United Nations Framework Convention On Climate Change (Protokol Kyoto Atas Konvensi Kerangka Kerja Perserikatan BangsaBangsa Tentang Perubahan Iklim) (Online). ( http://portal.mahkamahkonstitusi.go.id/eLaw/mg58ufsc89hrsg/uu172004.pdf diakses 2 Oktober 2009).

United Nations Framework Convention on Climate Change. Kyoto Protocol (Online). (http://unfccc.int/kyoto_protocol/items/2830.php diakses 2 Oktober 2009). 
United Nations Framework Convention on Climate Change. Kyoto Protocol Reference Manual (Online).

(http://unfccc.int/resource/docs/publications/08_unfccc_kp_ref_manual.pdf diakses 2 Oktober 2009).

Veith, S., Werner, J. R., \& Zimmermann, J. 2009. Competing Accounting Treatments for Emission Rights: A Capital Market Perspective (Online).

(http://papers.ssrn.com/sol3/papers.cfm?abstract_id=1323810 diakses 2 Oktober 2009).

Weygandt, J. J., Kieso, D. E., \& Kimmel, P. D. 2005. Accounting Principle, $7^{\text {th }}$ ed. New Jersey: John Wiley \& Sons, Inc. 